\title{
Correction to: Response to: "Does ACPA- negative RA consist of subgroups related to sustained DMARD-free remission and serological markers at disease presentation" by Masi and Fleischmann
}

Debbie M. Boeters ${ }^{1 *}$ and Annette H. M. van der Helm-van Mil ${ }^{1,2}$

Correction to: Arthritis Research \& Therapy (2020) 22:55

https://doi.org/10.1186/s13075-020-02152-9

Following publication of the original article [1], the authors reported an error.

In the last paragraph (first sentence) of the article it states that we have shown that "... higher MBDA scores at diagnosis associated with a lower risk to achieve DMARD-free remission over time...", however it should be "... higher MBDA scores at diagnosis associated with a higher risk to achieve DMARD-free remission over time..."

\section{Author details}

'Department of Rheumatology C1-R, Leiden University Medical Center, PO Box 9600, Leiden 2300, RC, the Netherlands. '2Department of Rheumatology, Erasmus University Medical Center, Rotterdam, the Netherlands.

Published online: 04 May 2020

\section{Reference}

1. Boeters DM, van der Helm-van Mil AHM. Response to: "Does ACPA-negative RA consist of subgroups related to sustained DMARD-free remission and serological markers at disease presentation" by Masi and Fleischmann. Arthritis Res Ther. 2020;22:55 https://doi.org/10.1186/s13075-020-02152-9.

The original article can be found online at https://doi.org/10.1186/s13075020-02152-9.

* Correspondence: D.M.Boeters@lumc.nl

${ }^{1}$ Department of Rheumatology C1-R, Leiden University Medical Center, PO Box 9600, Leiden 2300, RC, the Netherlands

Full list of author information is available at the end of the article

C C The Author(s). 2020 Open Access This article is licensed under a Creative Commons Attribution 4.0 International License, which permits use, sharing, adaptation, distribution and reproduction in any medium or format, as long as you give appropriate credit to the original author(s) and the source, provide a link to the Creative Commons licence, and indicate if changes were made. The images or other third party material in this article are included in the article's Creative Commons licence, unless indicated otherwise in a credit line to the material. If material is not included in the article's Creative Commons licence and your intended use is not permitted by statutory regulation or exceeds the permitted use, you will need to obtain permission directly from the copyright holder. To view a copy of this licence, visit http://creativecommons.org/licenses/by/4.0/ The Creative Commons Public Domain Dedication waiver (http://creativecommons.org/publicdomain/zero/1.0/) applies to the data made available in this article, unless otherwise stated in a credit line to the data. 